\title{
PEMETAAN BUDAYA: ARSITEKTUR CINA DI DESA BABAGAN-LASEM JAWA TENGAH
}

\author{
Mutiawati Mandaka', Ni Wayan Meidayanti Mustika ${ }^{2}$ \\ Program Studi Arsitektur, Fakultas Teknik, Universitas Pandanaran ${ }^{1}$ \\ Program Studi Arsitektur, Fakultas Teknik dan Perencanaan, Universitas Warmadewa ${ }^{2}$ \\ mutia.mandaka@unpand.ac.id ${ }^{1}$ \\ meidayanti.mustika@gmail.com²
}

\begin{abstract}
Of the many countries in the world that have a high level of culture, Indonesia is one of these countries. There are many historical relics found in the territory of Indonesia, one of which is Chinese culture. Cultural mapping is a community-based approach that aims to realize regional conservation. The case study raised in this cultural mapping is Chinese architecture in Babagan Lasem Village. Lasem was appointed because it has a history of developing one of the oldest Chinese settlements in Indonesia. The purpose of this paper is to find out the history of the development of the Babagan area, to map Chinese architectures and to provide recommendations. With a field survey approach for taking photos and plotting object coordinates in the field and supported by secondary data in the form of tracing references related to Babagan Lasem village. The results of the study recommend that there are eight buildings that can be included in the mapping of Chinese architecture in Babagan Village, namely the Gie Yong Bio temple, Om King Liang's house, Kim Jong's house, Hoo Hap building, Dinar Batik house, uncle Jun's house, Djarum's relative's house, Omah Sekar Kentjana Batik. By knowing the historical significance of the formation of Babagan Village through its architecture and spatial planning, it is hoped that the results can be used for mapping that is useful for village governments, Pokdarwis and academics (developing knowledge).
\end{abstract}

Keyword: cultural mapping; Chinese architecture; Babagan village

\begin{abstract}
Abstrak
Dari sekian banyak negara di dunia yang memiliki tingkat kebudayaan yang tinggi, Indonesia termasuk salah satu dari negara-negara tersebut. Banyak peninggalan bersejarah yang terdapat di wilayah Indonesia, salah satunya kebudayaan Cina. Cultural mapping merupakan sebuah pendekatan berbasis masyarakat yang bertujuan untuk mewujudkan pelestarian kawasan. Studi kasus yang diangkat pada cultural mapping kali ini adalah arsitektur Tionghoa di Desa Babagan Lasem. Lasem diangkat karena memiliki sejarah perkembangan salah satu permukiman Cina tertua di Indonesia. Tujuan paper ini adalah untuk mengetahui sejarah perkembangan kawasan Babagan, melakukan pemetaan arsitektur-arsitektur Tionghoa dan memberikan rekomendasi. Dengan pendekatan survey lapangan untuk pengambilan foto dan plot koordinat objek di lapangan dan didukung oleh data sekunder berupa penelusuran referensi-referensi terkait dengan desa Babagan Lasem. Hasil penelitian merekomendasikan ada delapan bangunan yang dapat dimasukkan kedalam pemetaan arsitektur Tionghoa yang ada di Desa Babagan yaitu klenteng Gie Yong Bio, rumah Om King Liang, omah Kim Jong, gedung Hoo Hap, omah Batik Dinar, omah om Jun, omah kerabat Djarum, omah Batik Sekar Kentjana. Dengan mengetahui signifikansi sejarah pembentukan Desa Babagan melalui arsitektur dan tata ruangnya, diharapkan hasilnya dapat digunakan untuk pemetaan yang bermanfaat untuk pemerintah desa, Pokdarwis dan akademisi (mengembangkan ilmu pengetahuan).
\end{abstract}

Kata Kunci: pemetaan budaya; arsitektur Tionghoa; desa Babagan

Info Artikel :

Diterima; 2021-10-20

Revisi; 2021-11-03

Disetujui; 2021-11-08

\section{PENDAHULUAN}

Lasem merupakan kecamatan di Kabupaten Rembang, Lasem sendiri memiliki julukan "Tiongkok Kecil" karena berdasarkan Pratiwo (2010) sekitar abad ke-13 orang China pertama kali tiba di Pulau Jawa, yang kemudian seiring berjalannya waktu mulai membangun permukiman permanen di bagian Timur sungai Lasem sekitar abad ke-15. Babagan merupakan salah satu desa yang lokasinya dekat dengan jalan raya di sebelah Barat dari Sungai Lasem, daerah ini dulunya merupakan daerah yang dibuka untuk orang-orang China yang melarikan diri dari Batavia akibat adanya pembantaian masal orang-orang China di Batavia. Sebagian besar yang takut bermigrasi 
di Lasem (Santoso et al., 2020) dan mulai menempati Desa Babagan ini. Dengan bertambahnya orang China yang bermukim di sini, maka mulailah didirikan sebuah kelenteng dengan nama Gie Yong Bio. Kelenteng ini menjadi pusat tempat ibadah dan menjadi tempat kegiatan warga sekitar. Lasem memiliki 20 desa salah satunya adalah desa Babagan. Dengan adanya permukiman Cina yang ada di Desa Babagan dan Desa sekitarnya maka membentuk sebuah kawasan Pecinan. Kawasan Pecinan sendiri menurut Fatimah (2014) adalah sebuah area dimana terdapat orangorang Cina dan keturunannya yang menghuni di daerah tersebut. Sedangkan Rudiyansyah (2014) berpendapat bahwa pecinan merupakan area bermukim orang-orang China atau Tionghoa secara berkelompok di daerah perkotaan. Di Desa Babagan sendiri terdapat beberapa peninggalan bangunan bersejarah yang memiliki arsitektur Tionghoa.

Cultural mapping merupakan sebuah pendekatan sistematis yang digunakan untuk merekam dan menampilkan informasi yang memberikan deskripsi karakteristik suatu tempat dan signifikansi budayanya (Pilai, 2013). Dengan adanya sejarah di masa lalu berikut perubahanperubahan yang terjadi dalam kurun waktu yang cukup lama di Desa Babagan maka perlu dilakukan mapping budaya agar peninggalan-peninggalan tersebut tidak hilang dan dapat bermanfaat di kemudian hari. Adapun tujuan mapping di Desa Babagan ini adalah untuk mengetahui signifikansi sejarah pembentukan Desa Babagan melalui arsitektur dan tata ruang.

\section{METODE PENELITIAN}

Metode yang digunakan pendekatan kualitatif deskriptif dengan pendekatan survey lapangan untuk pengambilan foto dan plot koordinat objek di lapangan dan didukung oleh data sekunder berupa penelusuran referensi-referensi terkait dengan desa Babagan Lasem.

\section{HASIL DAN PEMBAHASAN}

Pada dasarnya manusia hidup sangat berkaitan dengan lingkungan alaminya. Terjadi permukiman manusia dikarenakan ada hubungan timbal balik antara manusia dengan lingkungan alaminya. Menurut Pilai (2013), pembentukan permukiman yang berbeda budaya dikarenakan adanya transformasi ruang menjadi tempat dimana terdiri dari unsur-unsur dimensi lingkungan buatan manusia dalam membentuk permukiman, dimensi ekonomi dalam mencari mata pencaharian, dan dimensi sosial dalam membangun hubungan. Dapat dilihat pada transformasi Place-making berikut:

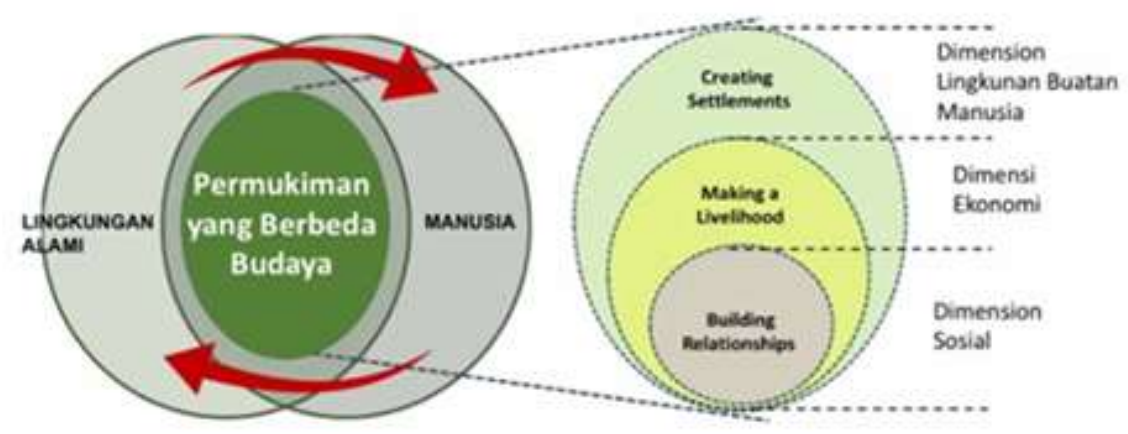

Gambar 1. Transformasi Ruang menjadi Tempat (Place-making)

Dari hubungan lingkungan dan manusia munculah lingkungan hidup buatan manusia, produk dan servis, kepercayaan dan amalan, ekspresi, estetik, ilmu dan keterampilan yang kesemuanya membentuk manifestasi budaya.

\section{Pemetaan Budaya}

Pemetaan budaya adalah pendekatan sistematis untuk mengidentifikasi, mencatat, dan menilai aset dan sumber daya lingkunngan alami dan terbina, aset social dan ekonomi, serta ekologi budaya yang unik pada suatu tempat (Pilai, 2013). Menurut Pilai yang diadaptasi dari Ghilardi (2009) pemetaan budaya membantu kita mengenali DNA sesuatu tempat dan komunitas. Pemetaan budaya telah dinyatakan oleh UNESCO sebagai alat dan metode penting untuk 
melestarikan warisan budaya dunia. Pemetaan ini dapat digunakan untuk benda yang tampak (tangible) maupun yang tidak tampak (intangible).

Budaya berkelanjutan (Sustainable Culture), Taylor (2013) mengacu pada manusia sebagai bagian dari alam dan warisannya, atau lanskap budaya, merupakan salah satu dari upaya untuk memelihara, melestarikan, merencanakan dan membangun dengan cara tersebut dapat diimplementasikan guna menambah nilai sosial dan ekonomi bagi masyarakat. Dengan demikian, esensi dari pemetaan budaya adalah kemampuan untuk mengidentifikasi dan mendokumentasikan potensi budaya, termasuk aspek-aspek tak berwujud yang terkait dengan unsur-unsur berwujud seperti kenangan, makna dan nilai, melalui penelitian terkait keragaman masyarakat.

\section{Prosedur pelakasanaan pemetaan budaya}

Menurut Pillai (2013), pemetaan budaya pada dasarnya terdiri dari 3 tahap yaitu persiapan, proses pemetaan dan evaluasi. Sebelum pemetaan dilakukan yaitu menentukan maksud dan tujuan, penentuan lokasi, identifikasi pemangku kepentingan dan kebutuhannya. Kemudian pada tahap pemetaan mengumpulkan dan mencatat data. Data mentah dikumpulkan, dianalisis, divisualisasikan, dan lebih mudah dipahami. Tahap evaluasi didasarkan pada faktor budaya, karakteristik wilayah yang akan dipetakan dan kepentingannya. Penilaian ini juga mencakup pengidentifikasian peluang dan kendala yang dapat digunakan untuk rencana yang relevan secara strategis dan budaya.

\section{Perencanaan Berbasis Budaya}

Pada dasarnya perencanaan berbasis budaya dibagi menjadi 2 tahapan, tahap pertama yaitu memahami site, tahap kedua yaitu menyusun perencanaan terpadu. Pemetaan budaya berada di tahap pertama pada langkah kedua setelah berkomunikasi dengan masyarakat dan pemangku kepentingan. Langkah ini merupakan dasar untuk sebuah perencanaan maupun pembangunan yang terintegrasi. (Pillai, 2013)

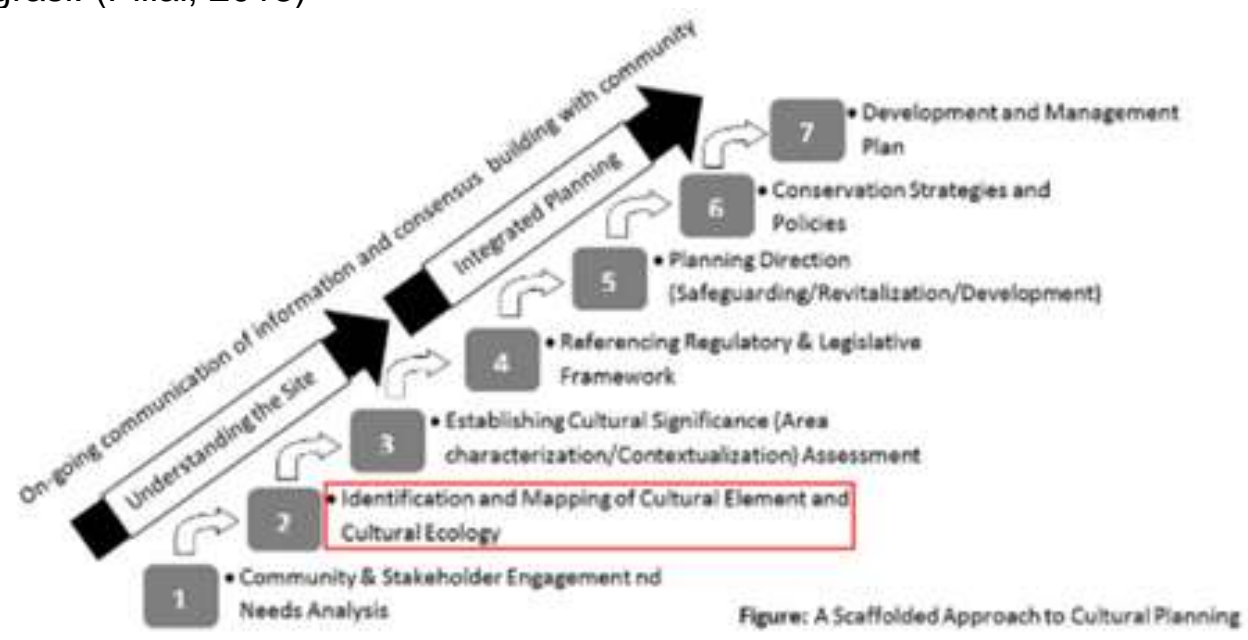

Gambar 2. Pendekatan untuk Perencanaan Budaya (Pillai, 2013)

Untuk memahami perencanaan yang berbasis budaya diawali melalui tahapan pertama yaitu memahami site. Untuk memahami site perlu melihat gambaran umum objek kemudian identifikasi lokasi dan selanjutnya masuk ke objek-objek yang akan dipetakan. Adapun gambaran umum di Desa Babagan terdapat bangunan-bangunan dengan arsitektur Tionghoa, bangunan bergaya Tionghoa ini tidak hanya terlihat pada kelenteng namun terdapat juga pada beberapa bangunan yang berfungsi sebagai tempat tinggal atau tempat usaha. Pada bangunan rumah tinggal, gaya arsitektur Tionghoa tidak selalu terlihat pada bentuk bangunan tapi juga terlihat dari detail ornamen atau pajangan.

\section{Identifikasi Lokasi}

Desa Babagan secara administratif berbatasan dengan wilayah sebelah utara Desa Gedongmulyo, sebelah selatan Desa Karasgede, sebelah timur Desa Karangturi, sebelah barat Desa 
Dorokandang. Jarak desa Babagan dengan pusat pemerintahan kecamatan hanya berjarak $2 \mathrm{~km}$ dan $13 \mathrm{~km}$ dari ibu kota kabupaten. Kondisi ini menjadi nilai tambah untuk mempercepat pembangunan yang ada. Desa Babagan terbagi menjadi $16 \mathrm{RT}$ dan $5 \mathrm{RW}$, berdasarkan data yang ada, jumlah penduduk Desa Babagan pada tahun 2021 adalah 2.663 jiwa, yang terdiri dari 1.366 orang laki-laki dan 1.297 ornag perempuan. Luas desa Babagan adalah 104,95 hektar, terutama berupa persawahan dan pemukiman.

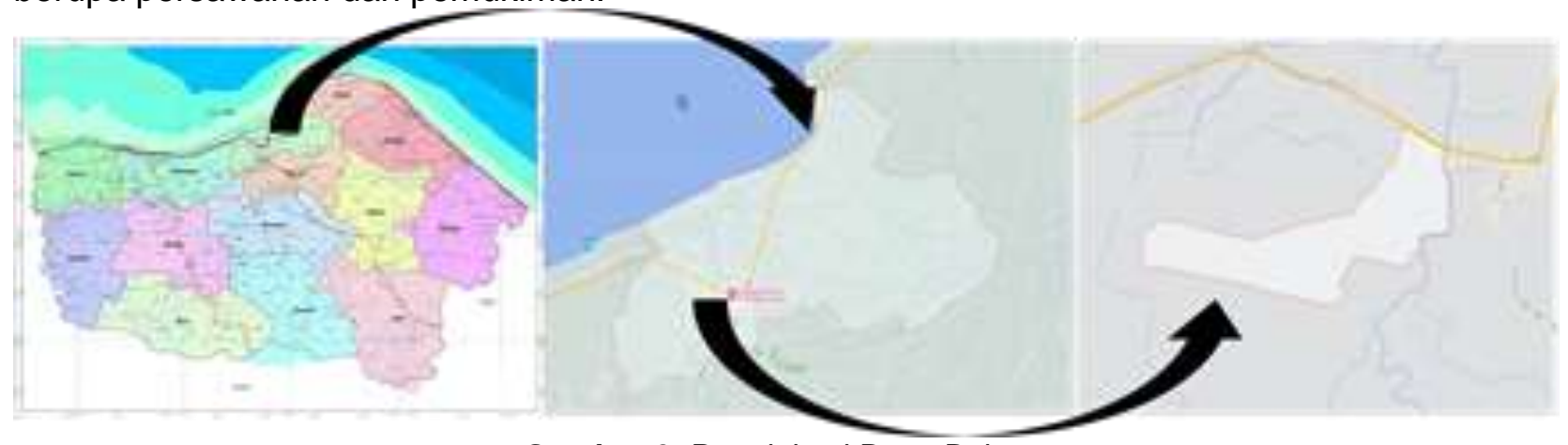

\section{Sejarah Desa Babagan}

Gambar 3. Peta lokasi Desa Babagan

Nama Babagan sendiri memiliki arti tempat berlabuh atau tempat sandar kapal atau perahu. Di era Majapahit, daerah ini masih menjadi area pelabuhan Samodra Welo yang meliputi Kaeringan (Kiringan), Sawah Segoro, Pohlandak hingga Bonang. Menurut Serat dan Babad Tanah Djawi, Pangeran Surowiyoto adalah Adipati Babagan Lasem. Sehingga dari catatan ini Babagan dulunya tempat kadipaten yang diperintah oleh Adipati Surowiyoto pada tahun 1477. Surowiyoto putra sulung Raden Patah dengan istrinya Sholeka (anak Wironegoro \& Nyai Ageng Maloka) menjadi Adipati Babagan Lasem di bawah Kerajaan Demak. Di abad ke 18 orang-orang Tionghoa mengungsi dari Batavia akibat peristiwa Kali Angke dan menetap di desa-desa sekitar Lasem. Pertambahan populasi orang Tionghoa di Lasem membuat api perlawanan kepada VOC semakin berkobar hingga puncaknya pada tahun 1740-1745 dan 1750 terdapat pertempuran warga Lasemgolongan Jawa, Santri, dan Tionghoa melawan VOC Belanda. Setelah perlawanan, rakyat Lasem dilumpuhkan oleh VOC, permukiman Tionghoa di pedesaaan Lasem dipindahkan ke sebelah barat sungai Lasem yang dinamakan Babagan. Kemudian Belanda membangun sebuah kantor urusan pribumi Lasem di Babagan (sebelum Kantor Kecamatan dipindah di desa Soditan).

\section{Pemetaan Bangunan Arsitektur di Desa Babagan}

1. Klenteng Gie Yong Bio

Didirikan tahun 1780 bersamaan dengan perkembangan penduduk China di daerah Babagan, klenteng Gie Yong Bio dibangun sebagai bentuk penghormatan untuk mengenang jasa ketiga pemimpin di Lasem yaitu Oei Ing Kiat (Raden Ngabehi Widyaningrat), Raden Panji Margono, Tan Kwee Wie yang berperang melawan VOC pada tahun 1740-an. Kelenteng Gie Yong Bio ini didirikan untuk mengenang jasa Panji Margana oleh komunitas orang-orang Tionghoa (Nurhajarini et al., 2015).

Klenteng tersebut kental akan ajaran Budhisme, Taoisme dan Konghuchu ini menjadi simbol kepahlawanan etnis Tionghoa dan etnis Jawa di Lasem secara khusus dan Rembang secara umum. Nama Gie Yong Kong Co yang memiliki arti "Kakek Nan Gagah" juga melekat sebagai julukan klenteng ini, karena nama tersebut untuk mengenang kepatriotan dan menghormati leluhur.

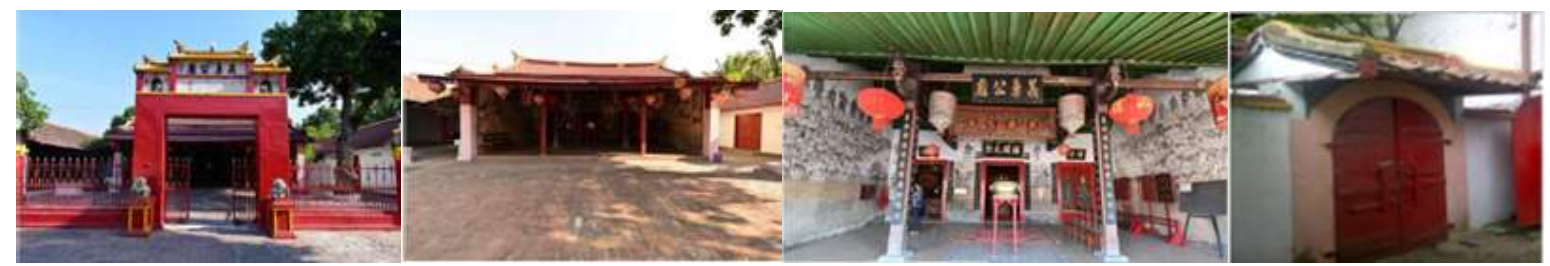

Gambar 4. Klenteng Gie Yong Bio 
Ciri khas arsitektur pada kelenteng ini adalah memiliki pagar masuk utama berbentuk gapura. Terdapat courtyard yang cukup luas di bagian depan bangunan kelenteng. Bentuk atap kelenteng memiliki bentuk Hsuan Shan. Menurut Indartoro (1987) pola tata ruang bangunan kelenteng terdiri dari ruang terbuka, ruang suci utama dan ruang dewa atau dewi pendamping. Di kelenteng Gie Yong Bio ini terdapat ruang penyembahan dewa-dewa dan beberapa detail ornamen seperti rangka kuda-kuda, patung di depan gapura kelenteng, dan tulisan aksara China pada kolom atau rangka atas pintu.

2. Rumah Ong Kim Liang (Omah Bah Beder)

Rumah ini dimiliki oleh pengusaha Bandeng Juwana, namun saat ini pemilik berdomisili di Jakarta. Rumah ini memiliki pagar terbuka, tidak seperti pagar rumah Tionghoa lainnya. Dari arsitekturnya terlihat bahwa bangunan rumah ini sudah mengalami akulturasi seperti terlihat pada bagian atap yang memiliki bentuk arsitektur kolonial. Bangunan dua lantai ini memiliki courtyard yang cukup luas di bagian depan rumah.

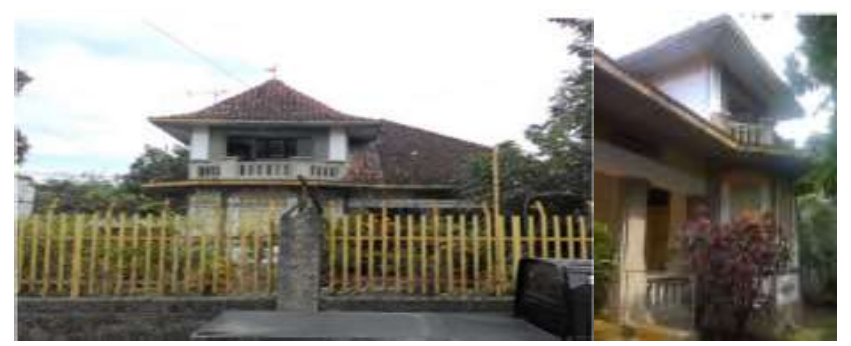

Gambar 5. Rumah Ong Kim Liang (Omah Bah Beder)

\section{Omah Kim Jong}

Pemiliknya dulu memiliki usaha garam dan usaha batik tulis lasem, namun setelah Kim Jong sudah meninggal dunia rumah ini menjadi tempat penjualan kayu-kayu atau furnitur kuno. Bangunan rumah ini sama dengan bangunan omah bah Beder, terdapat akulturasi arsitektur China dan kolonial. Hal tersebut dapat ditunjukkan pada bagian fasade bangunan yang terdapat gable di bagian atap, ada lengkung-lengkung di bawah atap pada teras depan bangunan dan balustrade di teras. Penataan courtyard pada bangunan omah Kim Jong ini masih dipertahankan dan diletakkan di bagian depan bangunan.

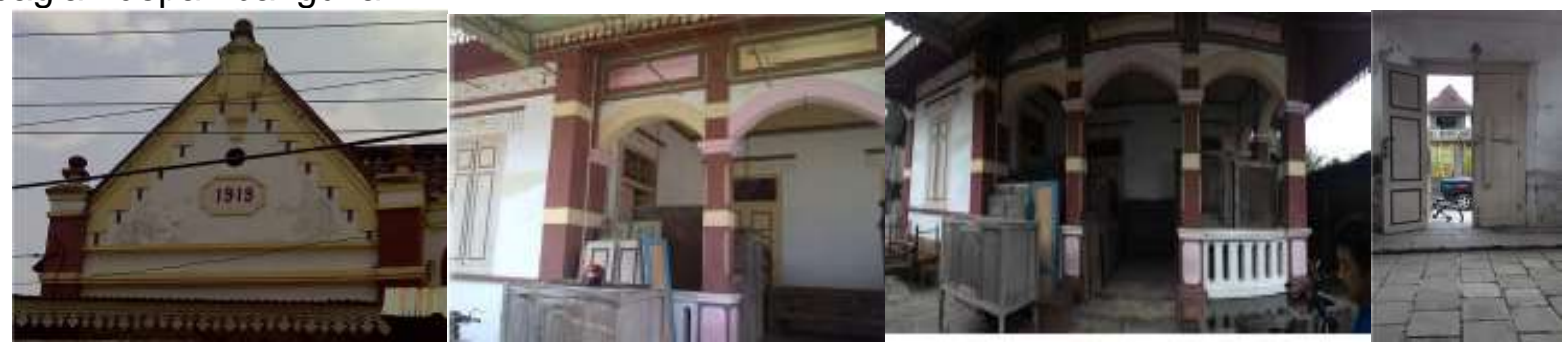

Gambar 6. Omah Kim Jong

\section{Gedung Hoo Hap}

Gedung ini merupakan tempat pertemuan orang-orang Tionghoa di Lasem. Bagian depan bangunan terdiri dari tiga pintu bertuliskan aksara China. Bentuk bangunan sendiri sudah berakulturasi dengan arsitektur kolonial. Bentuk atapnya sudah beradaptasi dengan lingkungan sekitar. Terdapat ruang tempat ibadah dilengkapi dengan meja persembahan dan patung. Pada bagian atap bangunan terdapat seperti cerobong asap yang menonjol. 


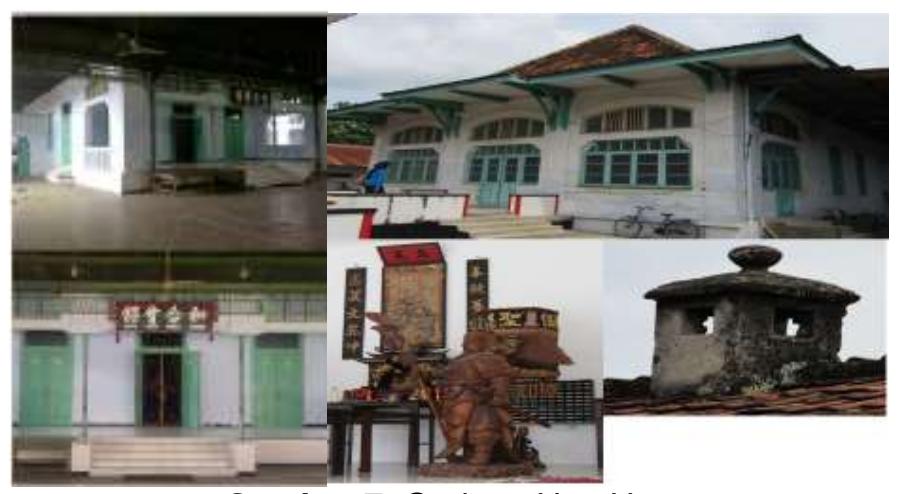

Gambar 7. Gedung Hop Hap

\section{Omah Batik Dinar}

Rumah ini sudah sejak lama tidak difungsikan, pada tahun 2000 rumah ini digunakan sebagai tempat membatik dengan nama Batik Dinar. Saat ini rumah tersebut digunakan sebagai tempat membatik bu Katrin. Bangunan ini sayangnya sudah tidak lengkap lagi, hanya tersisa pintu masuk berupa gapura dengan atap gerbang yang khas. Menurut Sudarwani et al. (2018) terdapat dua macam gerbang di Pecinan Lasem yaitu bentuk gerbang seperti gapura dan bentuk gerbang rumah. Selebihnya yang ada pada bangunan omah batik Dinar ini hanya tersisa bangunan penunjang yang berada di dalam dan kondisinya juga tidak terawat.

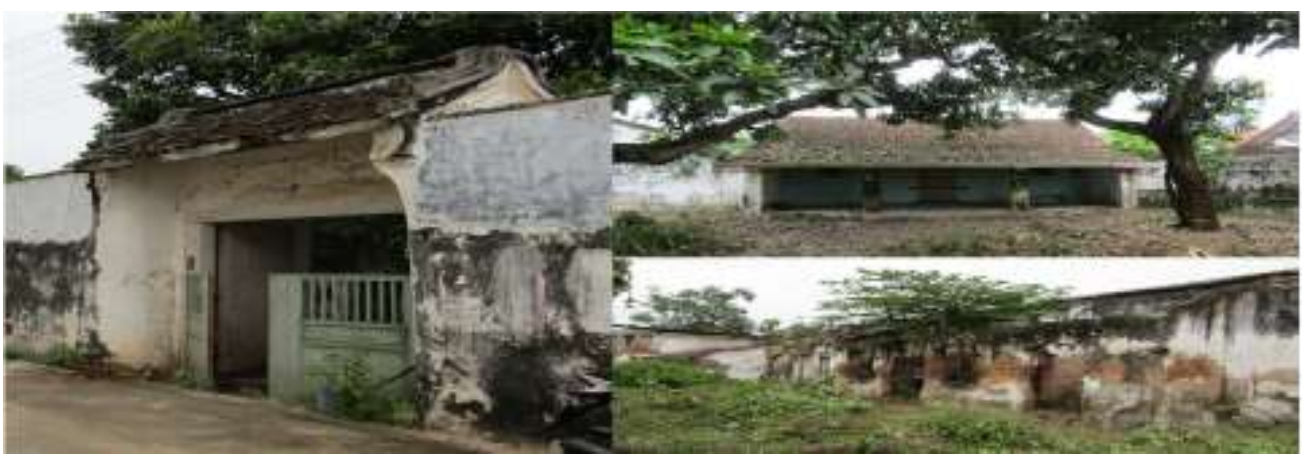

Gambar 8. Omah Batik Dinar

6. Omah Om Jun

Menurut pemiliknya sekarang, rumah ini dulunya merupakan tempat usaha criping pisang yang dijual ke Surabaya dan juga usaha garam. Jika dilihat secara arsitektural, bangunan ini memiliki pintu masuk (regol) khas China dengan pintu double berwarna merah. Bangunan utama masih asli dengan lantai terakota yang agak kropos dikarenakan efek dari garam. Dinding dan struktur bangunan utama menggunakan kayu yang masih asli, dengan kuda-kuda tao kung yang sangat khas terlihat di teras bagian depan rumah. Menurut Handjani dalam Kusdiwanggo et al (2021) ruangan utama rumah Tionghoa terdiri atas delapan ruang utama yaitu: (1) Pendapa, ruang depan dan (2) Teras rumah untuk menerima tamu, (3) Ruang tengah paling depan setelah teras berupa ruang altar sebagai tempat keluarga bersembahyang, (4) Ruangan dalam bagian belakang di balik altar yang dipisahkan oleh dinding, (5) Dua unit ruang tidur yang saling berhadapan untuk orangtua, (6) Dua unit ruang tidur untuk anak atau keluarga kandung, (7) Ruang belakang atau teras belakang yang berfungsi sebagai ruang makan, (8) Dapur yang terletak di teras belakang. 


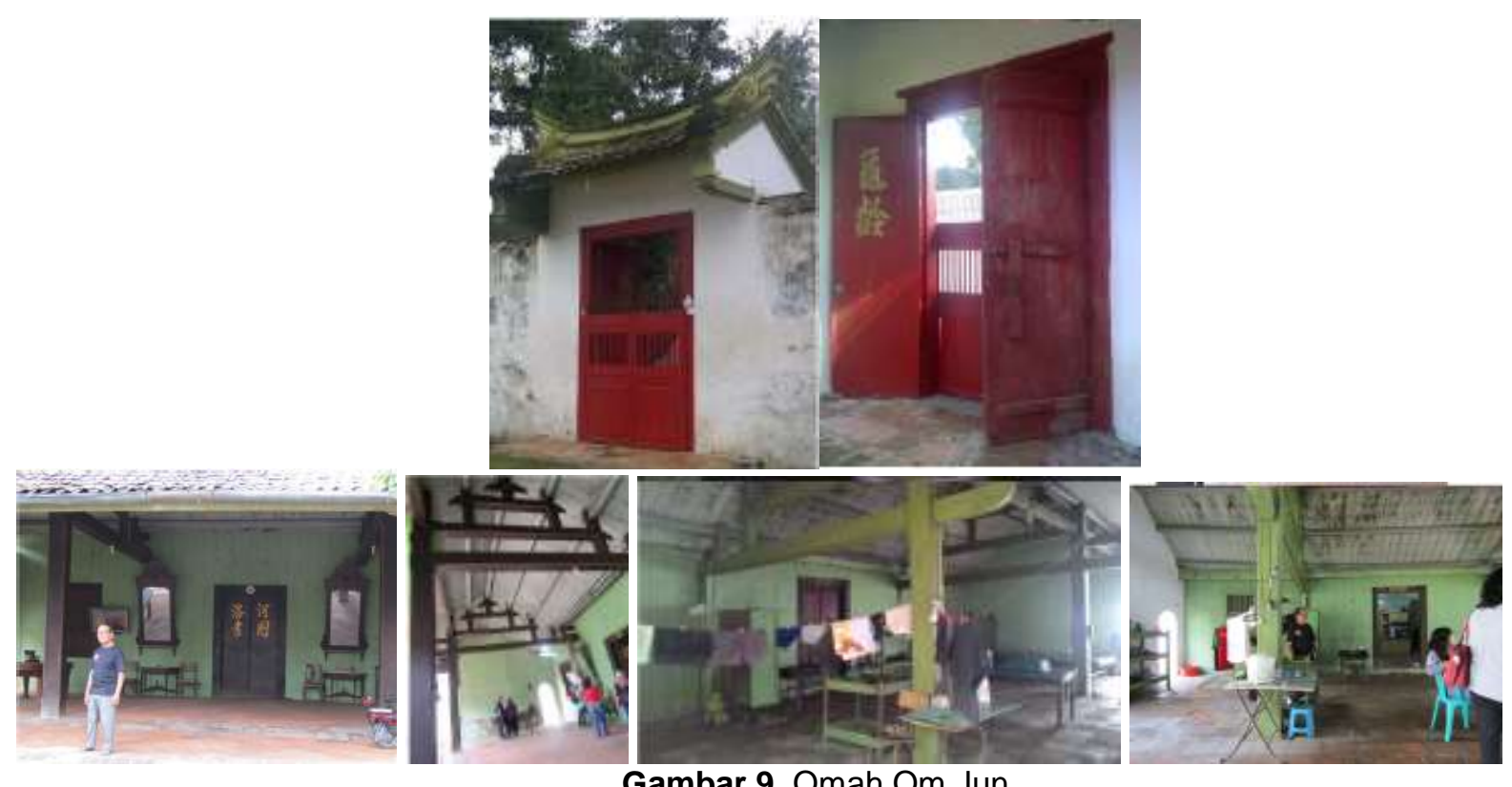

Bangunan omah om Jun ini dapat dikatakan bangunan representatif arsitektur Tionghoa di Lasem karena memiliki ciri-ciri arsitektur yang cukup lengkap mulai dari gerbang utama pintu masuk, courtyard, teras, detail arsitektur sampai dengan bentuk atap.

7. Omah Kerabat Djarum

Pemiliknya bernama Kwi Ing Ho saudara dari pemilik perusahaan Djarum yang memiliki usaha mercon di Rembang, memiliki 9 orang anak. Salah satunya yang menempati rumah tersebut adalah Kwi Jin Nyo atau biasa dipanggil Nyah Gin atau mak Gin.

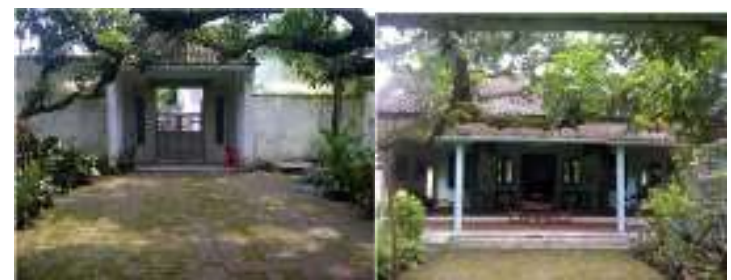

Gambar 10. Omah Kerabat Djarum

Rumah mak Gin ini telah mengalami akulturasi dengan budaya sekitarnya. Bagian gerbang pintu masuk biasanya beratapkan dengan bentuk Ngan Shan, namun pada gerbang atapnya menggunakan atap kemah tajuk. Terdapat courtyard di depan bangunan utama yang cukup luas. Bentuk denah simetris, dengan pintu utama di tengah dan kanan kiri terdapat jendela dengan ukuran yang besar. Teras depan cukup luas dengan lantai terakota dan terdapat penyangga atap dengan bentukan yang khas. Bagian kanan dan kiri teras terdapat pintu lengkung menuju bangunan samping.

8. Omah Batik Sekar Kentjana

Beralamatkan di Jalan Babagan Gang IV Nomor 4, Desa Babagan Kecamatan Rembang, pemiliki batik tulis Sekar Kentjana merupakan seorang Hoakiao (sebutan untuk keturunan China perantauan) yang telah lama atau sebagai pewaris yang paling lama menggeluti usaha kerajinan batik tulis Lasem yaitu Sigit Witjaksono.

Perusahaan batik tulis Lasem Sekar Kencana tidak memiliki toko / showroom yang berada di Desa Babagan. Hasil produksi kain batik tulisnya disimpan dan di-display di rumah produksi yang juga merupakan kediaman pribadi juragan. Rumah produksi batik tulis tersebut sangat mudah ditemukan dikarenakan bergaya khas rumah Tiongkok dengan pagar tembok menjulang tinggi, yang merupakan warisan dari leluhurnya secara turun temurun. Berkaitan dengan workshop perusahaan batik tulis Lasem Sekar Kencana yang merupakan warisan dari leluhurnya secara turun temurun tersebut, Pratiwo dalam Aziz (2014, p. 52) berpendapat bahwa, "Pemukiman orang 
Tionghoa di Lasem pada awalnya berada di Dasun, kemudian berkembang ke Babagan, hingga meluas ke Karangturi, di tengah kota Lasem pada abad XVIII".

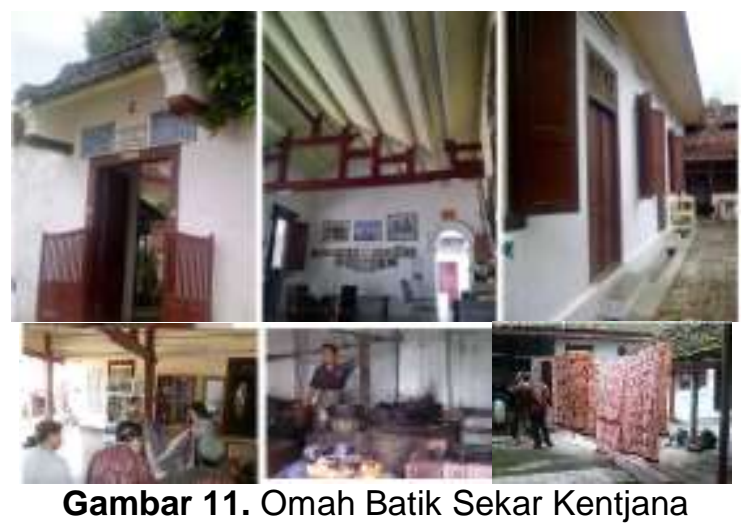

Berikut hasil plot titik koordinat ke-8 bangunan perwakilan dari kawasan Desa Babagan yang memiliki arsitektur Tionghoa di Lasem:

2021_Lasem Maps

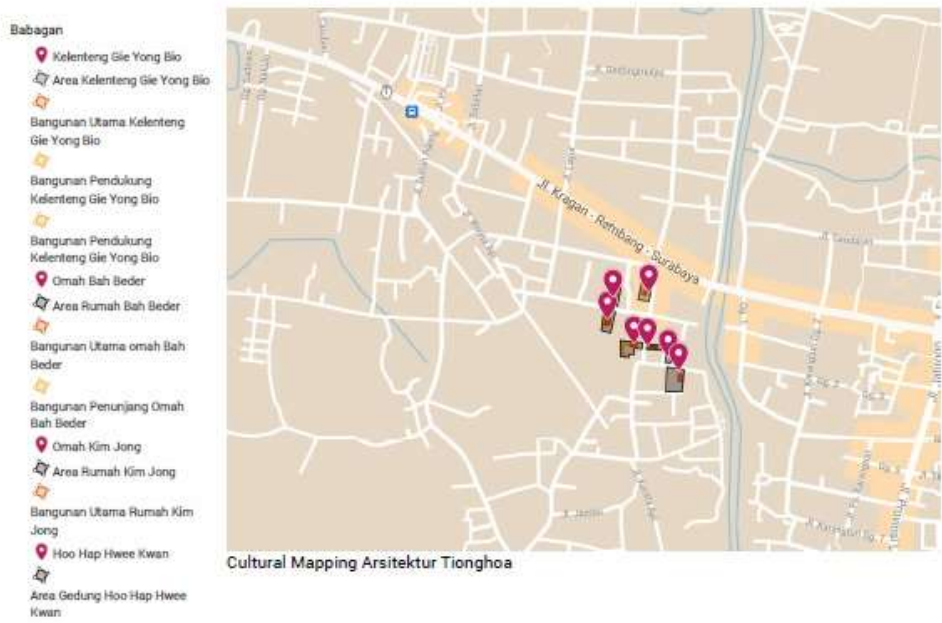

Gambar 12. Pemetaan Arsitektur Tionghoa di desa Babagan Lasem

\section{Pemetaan Budaya di Desa Babagan}

Pemetaan budaya di desa Babagan dilakukan melalui pendekan konteks sosial-budaya, konteks ekonomi dan konteks lingkungan. Hasil dari pemetaan adalah sebagai berikut:

\section{Konteks Sosial-Budaya}

Klenteng Gie Yong Bio hingga saat ini masih digunakan untuk tempat ibadah maupun kegiatan sosial warga Tionghoa yang berada di Desa Babagan dan sekitarnya. Klenteng Gio Yong Bio juga berpengaruh dalam mempromosikan budaya daerah Lasem. Melalui klenteng ini masyarakat dapat mengetahui budaya Tionghoa di Lasem baik itu dari arsitektur bangunan dan beragam kesenian yang ada.

\section{Konteks Ekonomi}

Penataan ruang beberapa rumah yang berarsitektur Tionghoa memanfaatkan lahan rumah mereka untuk kegiatan perekonomian seperti proses membatik, pengeringan makanan (criping), dan lainlain.

\section{Konteks Lingkungan}

Lingkungan bangunan-bangunan rumah berarsitektur Tionghoa dengan dinding bangunan yang cukup tinggi menjadi ikonik di Desa Babagan, sedangan untuk pembuangan limbah pemrosesan batik masih belum menggunakan IPAL secara komunal. 
Selanjutnya dari hasil pemetaan tersebut dilakukan analisa untuk menghasilkan rekomendasi, analisa SWOT digunakan untuk mendapatkan hasil yang sesuai capaian.

Tabel 1. Analisa SWOT Pemetaan Budaya di Desa Babagan Lasem

\begin{tabular}{|c|c|c|c|}
\hline Strength & Weakness & Opportunity & Threat \\
\hline $\begin{array}{l}\text { - Memiliki } \\
\text { peninggalan } \\
\text { budaya yang } \\
\text { kaya dengan } \\
\text { jumlah yang } \\
\text { tidak sedikit }\end{array}$ & $\begin{array}{l}\text { - Kemampuan } \\
\text { untuk } \\
\text { mempertahanka } \\
\mathrm{n} \text { bangunan } \\
\text { lama } \\
\text { membutuhkan } \\
\text { biaya yang tidak } \\
\text { sedikit } \\
\text { - Selama } \\
\text { beberapa tahun } \\
\text { terakhir mulai } \\
\text { bermunculan } \\
\text { pedagang yang } \\
\text { mendirikan } \\
\text { bangunan } \\
\text { nempel di } \\
\text { tebok-tembok } \\
\text { sehingga } \\
\text { menghilangkan } \\
\text { luasan lahan } \\
\text { jalan semakin } \\
\text { sempit juga } \\
\text { tidak sedap } \\
\text { dipandang mata }\end{array}$ & 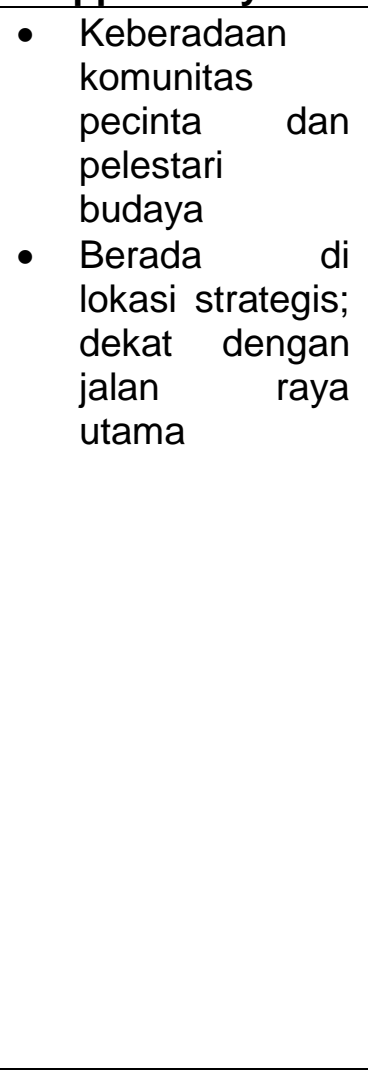 & $\begin{array}{l}\text { - Ada pihak- } \\
\text { pihak yang } \\
\text { belum } \\
\text { memahami } \\
\text { prinsip } \\
\text { pelestarian, } \\
\text { sehingga } \\
\text { beberapa } \\
\text { objek dipugar } \\
\text { tanpa } \\
\text { memperhatika } \\
\text { n prinsip } \\
\text { pelestarian }\end{array}$ \\
\hline
\end{tabular}

\section{KESIMPULAN DAN SARAN}

Dengan mengetahui signifikansi sejarah pembentukan Desa Babagan melalui arsitektur dan tata ruangnya, diharapkan hasilnya dapat digunakan untuk pemetaan yang bermanfaat untuk pemerintah desa, Pokdarwis dan akademisi (mengembangkan ilmu pengetahuan).

Selanjutnya dengan potensi Desa Babagan yang sangat bagus ini direkomendasikan agar pemerintahan juga segera mewujudkan Desa Babagan sebagai salah satu Warisan Budaya Nasional (Cagar Budaya) dan kedepannya lingkungan dan pariwisata yang berkelanjutan perlu direncanakan lagi.

\section{UCAPAN TERIMA KASIH}

Paper ini merupakan riset bersama antara Universitas Pandanaran Semarang bekerjasama dengan Universitas Warmadewa Bali sebagai wujud dari darma penelitian. Terimakasih kepada pihak yang memberikan kontribusi data dari Desa Babagan, kelompok belajar dan komunitas Lasem, dan pihak-pihak yang tidak dapat disebutkan satu per satu.

\section{DAFTAR PUSTAKA}

Aziz, M. (2014). Lasem Kota Tiongkok Kecil. Penerbit Ombak.

Fatimah, T. (2014). Sejarah Kawasan Pecinan Pancoran-Glodok Dalam Konteks Lokalitas Kampung Kota Jakarta. Prosiding Architecture Event 2014, 129-139.

Indarto, L. (1987). Pola Tata Ruang Bangunan Kelenteng.

Kusdiwanggo, et al. (2021). Arsitektur Lasem yang berjaya dan yang runtuh (P. Pratikno (ed.)). Penerbit Pohon Cahaya.

Nurhajarini, D. R., Purwaningsih, E., \& Fibiona, I. (2015). Akulturasi Lintas Zaman di Lasem: Perspektif Sejarah dan Budaya (Kurun Niaga-Sekarang). http://repositori.kemdikbud.go.id/id/eprint/1131 
Pilai, J. (2013). Cultural Mapping: A Guide to Understanding Place, Community and Continuity. Strategic Information and Research Development Centre (SIRDC).

Pratiwo, \& Nazir, S. . (2010). Arsitektur Tradisional Tionghoa dan Perkembangan Kota. Ombak.

Rudiansyah. (2014). Tipologi dan Makna Simbolis Rumah Tjong A Fie di Kota Medan. Estilisium.

Santoso, R. E., Sari, S. R., \& Rukayah, R. S. (2020). Peran Masyarakat Tionghoa Terhadap Perkembangan Kawasan Heritage Di Kota Lasem, Kabupaten Rembang. Modul, 20(2), 8497. https://doi.org/10.14710/mdl.20.2.2020.84-97

Sudarwani, M. M., Purwanto, E., \& Rukhayah, S. (2018). AKULTURASI DALAM ARSITEKTUR RUMAH TINGGAL LASEM: Studi Kasus Rumah Liem King Siok. Sabda: Jurnal Kajian Kebudayaan, 13(2), 158. https://doi.org/10.14710/sabda.13.2.158-168

Taylor, K. (2013). Cultural Mapping: Intangible Values and Engaging with Communities with Some Reference to Asia. The Historic Environment, 4(1), 50-61. 